\title{
Front Matter: Volume 8543
}

, "Front Matter: Volume 8543," Proc. SPIE 8543, Technologies for Optical Countermeasures IX, 854301 (2 July 2013); doi: 10.1117/12.2017025

SPIE. Event: SPIE Security + Defence, 2012, Edinburgh, United Kingdom 


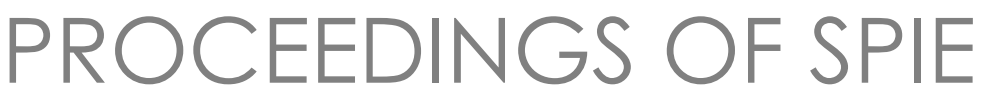

\section{Technologies for Optical Countermeasures IX}

David H. Titterton

Mark A. Richardson

Editors

26-27 September 2012

Edinburgh, United Kingdom

Sponsored by

SPIE

Cosponsored by

SELEX GALILEO • THALES

Delivered with the support of

Scottish Development International - Scottish Enterprise

Cooperating Organisations

DSTL (United Kingdom) • IOP Instrument Science and Technology Group (United Kingdom) Scottish Optoelectronics Association (United Kingdom)

Electronics Sensors and Photonics Knowledge Transfer Network (United Kingdom)

Published by

SPIE

Volume 8543

Proceedings of SPIE 0277-786X, v.8543

SPIE is an international society advancing an interdisciplinary approach to the science and application of light.

Technologies for Optical Countermeasures IX, edited by David H. Titterton, Mark A. Richardson,

Proc. of SPIE Vol. 8543, 854301 - @ 2012 SPIE · CCC code: 0277-786/12/\$18 · doi: 10.1117/12.2017025 
The papers included in this volume were part of the technical conference cited on the cover and title page. Papers were selected and subject to review by the editors and conference program committee. Some conference presentations may not be available for publication. The papers published in these proceedings reflect the work and thoughts of the authors and are published herein as submitted. The publisher is not responsible for the validity of the information or for any outcomes resulting from reliance thereon.

Please use the following format to cite material from this book:

Author(s), "Title of Paper," in Technologies for Optical Countermeasures IX, edited by David H. Titterton, Mark A. Richardson, Proceedings of SPIE Vol. 8543 (SPIE, Bellingham, WA, 2012) Article CID Number.

ISSN: 0277-786X

ISBN: 9780819492845

Published by

SPIE

P.O. Box 10, Bellingham, Washington 98227-0010 USA

Telephone +1 3606763290 (Pacific Time) · Fax +1 3606471445

SPIE.org

Copyright (C) 2012, Society of Photo-Optical Instrumentation Engineers.

Copying of material in this book for internal or personal use, or for the internal or personal use of specific clients, beyond the fair use provisions granted by the U.S. Copyright Law is authorized by SPIE subject to payment of copying fees. The Transactional Reporting Service base fee for this volume is $\$ 18.00$ per article (or portion thereof), which should be paid directly to the Copyright Clearance Center (CCC), 222 Rosewood Drive, Danvers, MA 01923. Payment may also be made electronically through CCC Online at copyright.com. Other copying for republication, resale, advertising or promotion, or any form of systematic or multiple reproduction of any material in this book is prohibited except with permission in writing from the publisher. The CCC fee code is 0277-786X/12/\$18.00.

Printed in the United States of America.

Publication of record for individual papers is online in the SPIE Digital Library.

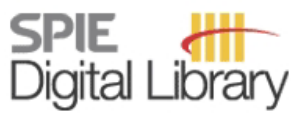

SPIEDigitalLibrary.org

Paper Numbering: Proceedings of SPIE follow an e-First publication model, with papers published first online and then in print and on CD-ROM. Papers are published as they are submitted and meet publication criteria. A unique, consistent, permanent citation identifier (CID) number is assigned to each article at the time of the first publication. Utilization of CIDs allows articles to be fully citable as soon as they are published online, and connects the same identifier to all online, print, and electronic versions of the publication. SPIE uses a six-digit CID article numbering system in which:

- The first four digits correspond to the SPIE volume number.

- The last two digits indicate publication order within the volume using a Base 36 numbering

system employing both numerals and letters. These two-number sets start with 00, 01, 02, 03, 04, 05, 06, 07, 08, 09, 0A, OB ... 0Z, followed by 10-1Z, 20-2Z, etc.

The CID Number appears on each page of the manuscript. The complete citation is used on the first page, and an abbreviated version on subsequent pages. Numbers in the index correspond to the last two digits of the six-digit CID Number. 


\section{Contents}

vii Conference Committee

\section{SESSION 1 KEYNOTE SESSION}

854302 Trends in electro-optical electronic warfare (Keynote Paper) [8543-1]

C. R. Smith, R. Grasso, J. Pledger, N. Murarka, Northrop Grumman Electronic Systems

(United States)

854303 Laser manufacturing: strategies for dealing with the challenges (Keynote Paper) [8543-2]

J. R. M. Barr, SELEX Galileo Ltd. (United Kingdom)

\section{SESSION $2 \quad$ QCLS}

854304 Quantum cascade lasers ready for IRCM applications (Invited Paper) [8543-3]

M. Razeghi, Northwestern Univ. (United States)

854306 A hollow waveguide integrated optic QCL beam combiner [8543-5]

I. F. Elder, R. A. Lamb, SELEX Galileo Ltd. (United Kingdom); R. M. Jenkins, HollowGuide Ltd.

(United Kingdom)

\section{SESSION 3 TWO MICRON I}

854307 Efficient single-pass resonantly-pumped Ho:YAG laser (Invited Paper) [8543-6]

I. Elder, SELEX Galileo Ltd. (United Kingdom); T. Kendall, Defence Science and Technology Lab. (United Kingdom)

854308 Fiber laser pumped high energy cryogenically cooled Ho:YLF laser (Invited Paper) [8543-7] E. Lippert, H. Fonnum, K. Stenersen, Norwegian Defence Research Establishment (Norway)

854309 Operation improvement of side-pumped Er:Yb:glass lasers through optical compensation techniques [8543-8]

M. Vitiello, E. Spinozzi, GEM Elettronica S.r.l. (Italy)

8543 OA Single longitudinal mode and dual wavelength CW VBG lasers at 1342nm and $1064 \mathrm{~nm}$ [8543-9]

A. White, I. Elder, G. Hall, SELEX Galileo Ltd. (United Kingdom)

\section{SESSION 4 TWO MICRON II}

8543 OD MILDA: mid-infrared laser source for DIRCM application [8543-12]

B. Crépy, G. Closse, S. Cussat-Blanc, M. Le Nevé, J. Montagne, P. Morin, O. Squaglia, CILAS Orléans (France); B. Mellier, DGA-MI (France) 
8543 OE Demonstration of a wavelength selected optically pumped $\mathrm{HBr}$ laser [8543-13]

W. Koen, C. Jacobs, C. Bollig, H. J. Strauss, L. L. Botha, M. J. D. Esser, Council for Scientific

and Industrial Research (South Africa)

\section{SESSION 5 LASER EFFECTS}

8543 OF Optics detection using a dual channel approach (Invited Paper) [8543-14]

L. Sjöqvist, L. Allard, G. Bolander, M. Pettersson, Swedish Defence Research Agency

(Sweden); S. Edström, Defence Materiel Administration (Sweden)

$8543 \mathrm{OH} \quad$ Coherent source transverse field profiles and far-field energy distribution [8543-26]

R. Meyer, Northrop Grumman Electronic Systems (United States)

\section{SESSION $6 \quad$ MODELLING AND SIMULATION I}

$8543 \mathrm{Ol} \quad$ Modelling infrared signatures of ships and decoys for countermeasures effectiveness studies (Invited Paper) [8543-18]

R. H. M. A. Schleijpen, M. A. C. Degache, H. E. T. Veerman, R. van Sweeden,

B. A. Devecchi, TNO Defence, Security and Safety (Netherlands)

8543 0J Pyradi: an open-source toolkit for infrared calculation and data processing (Invited Paper) [8543-19]

C. J. Willers, Council for Scientific and Industrial Research (South Africa); M. S. Willers, Denel Dynamics (South Africa); R. A. T. Santos, ITA (Brazil); P. J. van der Merwe, Denel Dynamics (South Africa); J. J. Calitz, A. de Waal, A. E. Mudau, Council for Scientific and Industrial Research (South Africa)

8543 OK Modelling of self phase modulation for broadband DIRCM lasers [8543-20]

R. A. Lamb, SELEX Galileo Ltd. (United Kingdom)

$8543 \mathrm{OL}$ An intelligent tracking algorithm for an imaging infrared anti-ship missile [8543-21]

G. J. Gray, N. Aouf, M. A. Richardson, Cranfield Univ. (United Kingdom); B. Butters, Meon Technology Ltd. (United Kingdom); R. Walmsley, Chemring Countermeasures Ltd. (United Kingdom)

8543 OM Simulating the DIRCM engagement: component and system level performance (Invited Paper) [8543-22]

C. J. Willers, Council for Scientific and Industrial Research (South Africa); M. S. Willers, Denel Dynamics (South Africa)

8543 ON Key considerations in infrared simulations of the missile-aircraft engagement (Invited Paper) [8543-23]

M. S. Willers, Denel Dynamics (South Africa); C. J. Willers, Council for Scientific and Industrial Research (South Africa) 
$854300 \quad$ Future-proofing an aircraft self-protection IR signature database [8543-24]

M. Alayed, M. M. El-Desouki, M. S. Alsawadi, K. Alghamdi, King Abdulaziz City for Science and Technology (Saudi Arabia); A. A. Al-Ghamdi, King Abdulaziz Univ. (Saudi Arabia);

C. J. Willers, A. E. Mudau, D. F. Bezuidenhout, Council for Scientific and Industrial Research (South Africa)

8543 OP Aircraft plume infrared radiance inversion and subsequent simulation model [8543-25] S. J. P. Retief, Denel Dynamics (South Africa)

POSTER SESSION

8543 OR The European air defence high-energy laser weapon project [8543-17]

K. Diener, French-German Research Institute of Saint-Louis (France); R. Protz, MBDA

Germany (Germany)

Author Index 
Proc. of SPIE Vol. $8543854301-6$

Downloaded From: https://www.spiedigitallibrary.org/conference-proceedings-of-spie on 26 Apr 2023 Terms of Use: https://www.spiedigitallibrary.org/terms-of-use 


\title{
Conference Committee
}

\author{
Symposium Chairs
}

David H. Titterton, Defence Science and Technology Laboratory

(United Kingdom)

Reinhard R. Ebert, Fraunhofer-Institut für Optronik, Systemtechnik und

Bildauswertung (Germany)

Conference Chairs

David H. Titterton, Defence Science and Technology Laboratory

(United Kingdom)

Mark A. Richardson, Cranfield University (United Kingdom)

Conference Programme Committee

Zahir Daya, Defence Research and Development Canada, Atlantic (Canada)

Brian Butters, Chemring Countermeasures Ltd. (United Kingdom)

Marc Eichhorn, Institut Franco-Allemand de Recherches de SaintLouis (France)

Ian F. Elder, SELEX Galileo Ltd. (United Kingdom)

Robert J. Grasso, Northrop Grumman Electronic Systems (United States)

Helena Jelinková, Czech Technical University in Prague (Czech Republic)

Stephen P. McGeoch, Thales Optronics Ltd. (United Kingdom)

Espen Lippert, Norwegian Defence Research Establishment (Norway)

Benoit Mellier, DGA/DCE/CELAR (France)

Ric H. M. A. Schleijpen, TNO Defence, Security and Safety (Netherlands)

Dirk Peter Seiffer, Fraunhofer-Institut für Optronik, Systemtechnik und Bildauswertung (Germany)

Ove Steinvall, Swedish Defence Research Agency (Sweden)

Mark R.G. Taylor, Defence Science and Technology Organisation (Australia)

Hans Dieter Tholl, Diehl BGT Defence GmbH \& Company KG

(Germany)

Maria Willers, Denel Dynamics (South Africa)

Nellis Willers, Council for Scientific and Industrial Research (South Africa) 
Session Chairs

1 Keynote Session

Robert J. Grasso, Northrop Grumman Electronic Systems (United States)

2 QCLS

Lars J. Sjöqvist, Swedish Defence Research Agency (Sweden)

3 Two Micron I

Ric H. Schleijpen, TNO Defence, Security and Safety (Netherlands)

4 Two Micron II

Ian F. Elder, SELEX Galileo Ltd. (United Kingdom)

5 Laser Effects

Hans Dieter Tholl, Diehl BGT Defence GmbH \& Company KG (Germany)

6 Modelling and Simulation I

Lars J. Sjöqvist, Swedish Defence Research Agency (Sweden)

$7 \quad$ Modelling and Simulation II

Ian F. Elder, SELEX Galileo Ltd. (United Kingdom) 